\title{
From Ejtm (European Journal of Translational Myology) to Ejt3M (European Journal of Translational Myology, Mobility, Medicine)
}

\author{
Sergio Adamo \\ Department of Anatomy, Histology, Forensic Medicine and Orthopedics, Sapienza University of \\ Rome, Italy - E-mail: sergio.adamo@uniromal.it \\ This article is distributed under the terms of the Creative Commons Attribution Noncommercial License (CC BY-NC 4.0) which permits
} any noncommercial use, distribution, and reproduction in any medium, provided the original author(s) and source are credited.

\begin{abstract}
This first 2018 Issue of the European Journal of Translational Myology presents many novelties, that are demonstrating that the journal is vital and expanding its authorship, readership and relevance from focused fields of biology, physiology, diagnostic, management and rehabilitation of skeletal muscle tissue to the more interesting and clinical relevant fields of human mobility up to those of general medicine. The Editorial Board is consequently expanded to allow fair and expert evaluation of more broadly interests and expertise of the Authors submitting typescripts. We are considering the option to move the name of the journal from Ejtm to Ejt3M (Myology, Mobility, Medicine). Criticisms and suggestions are welcomed.
\end{abstract}

Key Words: Ejtm, Ejt3M, translational myology, mobility, medicine

Eur J Transl Myol 28 (1): 1-2, 2018

The first issue of the Volume 28, 2018 of the European Journal of Translational Myology (Ejtm) opens with the collection of Abstracts of the 2018Spring PaduaMuscleDays, ${ }^{1}$ an event dedicated to the research activities and the personality of Giovanni Salviati, who we were so unlucky to lose him in the best of his fifties. ${ }^{2}$ Many of his Colleagues and Pupils will gather next March 15-17 to Padova and Euganei Hills to stress the importance for them and for the field of skeletal muscle of the important contributions of Giovanni to the fields of Myology. ${ }^{3}$ The 2018Spring PaduaMuscleDays will be a Myology event, but the interests will move from the analyses in single muscle fibers to their impact to Mobility of the people and to its impact in the broad fields of muscle Medicine, from genetic muscle diseases to aging. ${ }^{4-16}$ A few examples are the talk of Lee Sweeney presented March 15, 2018, ${ }^{17}$ and the Opening Lecture of the Giovanni Salviati Memorial by Roger Sabbadini (March 16, 2018) on the potential of the Lypidomics in cancer managements. ${ }^{19-22} \mathrm{We}$ are thus wondering if we have to change the meaning of the acronym Ejtm from European Journal of Translational Myology to include the very heterogeneous collection of papers that the journal is attracting (see the index of the Volume 28 (1), 2018). ${ }^{23}$ To start the process a new section of the journal is included in the list of Ejtm Advisors, that now includes the Section: Mobility Medicine, Helmut Kern and Giorgio Vescovo, Eds. They are, indeed, excellent Myologists, but their interests and results span very far from structure/function of the skeletal muscle tissue in health and disease. The Advisors of Ejtm are inviting potential Authors of the incoming Ejt3M (Myology, Mobility, Medicine) to submit typescripts, taking into account that the journal is keen to publish high level papers in the fields of Myology, Mobility and Medicine.

\section{Acknowledgments and Funding}

This typescript is sponsored by the $\mathrm{A} \& \mathrm{C}$ M-C Foundation for Translational Myology, Padova, Italy.

\section{Conflict of Interest}

The author declares to have none conflict of interests.

\section{Ethical Publication Statement}

Author confirms that he has read the Journal's position on issues involved in ethical publication and affirms that this report is consistent with those guidelines.

\section{Corresponding Authors}

Sergio Adamo, Department of Anatomy, Histology, Forensic Medicine and Orthopedics, Sapienza University of Rome, Italy.

E-mail: sergio.adamo@uniroma1.it

\section{References}

1. Carraro U. Exciting perspectives for Translational Myology in the Abstracts of the 2018Spring PaduaMuscleDays: Giovanni Salviati Memorial - 
Chapter I - Foreword. Eur J Transl Myol 2018;28:3-9

2. Rizzuto N. Introduction. Italian J Neurol Sci 1990;20:365.

3. Margreth A, Salviati G, Carraro U. Neural control on the activity of the calcium-transport system in sarcoplasmic reticulum of rat skeletal muscle. Nature 1973;241(5387):285-6.

4. Pigna E, Greco E, Morozzi G, et al. Denervation does not Induce Muscle Atrophy Through Oxidative Stress. Eur J Transl Myol 2017;27:6406. doi: 10.4081/ejtm.2017.6406. eCollection 2017 Feb 24.

5. Coste CA, Mayr W, Bijak M, et al. FES in Europe and Beyond: Current Translational Research. Eur J Transl Myol. 2016;26:6369. doi: 10.4081/ejtm.2016.6369. eCollection 2016 Sep 15.

6. Scicchitano BM, Sica G, Musarò A.Stem Cells and Tissue Niche: Two Faces of the Same Coin of Muscle Regeneration. Eur J Transl Myol 2016;26:6125. doi: 10.4081/ejtm.2016.6125. eCollection 2016 Sep 15.

7. Lavorato M, Gupta PK, Hopkins PM, FranziniArmstrong C. Skeletal Muscle Microalterations in Patients Carrying Malignant Hyperthermia-Related Mutations of the e-c Coupling Machinery. Eur J Transl Myol2016;26:6105. doi: 10.4081/ejtm. 2016.6105. eCollection 2016 Sep 15.

8. Carotenuto F, Coletti D, Di Nardo P, Teodori. L $\alpha$ Linolenic Acid Reduces TNF-Induced Apoptosis in C2C12 Myoblasts by Regulating Expression of Apoptotic Proteins. Eur J Transl Myol 2016;26:6033. doi: 10.4081/ejtm. 2016.6033. eCollection 2016 Sep 15.

9. Mosole S, Carraro U, Kern H, et al. Use it or Lose it: Tonic Activity of Slow Motoneurons Promotes Their Survival and Preferentially Increases Slow Fiber-Type Groupings in Muscles of Old Lifelong Recreational Sportsmen. Eur J Transl Myol 2016;26:5972. doi: 10.4081/ ejtm.2016.5972. eCollection 2016 Sep 15.

10. Edmunds KJ, Gíslason MK, Arnadottir ID, et al. Quantitative Computed Tomography and Image Analysis for Advanced Muscle Assessment. Eur J Transl Myol 2016;26:6015. doi: 10.4081/ejtm. 2016.6015. eCollection 2016 Jun 13.

11. Coletti D, Daou N, Hassani M, et al. Serum Response Factor in Muscle Tissues: From Development to Ageing. Eur J Transl Myol 2016;26:6008. doi: 10.4081/ejtm.2016. 6008 . eCollection 2016 Jun 13.

12. Hiroux C, Vandoorne T, Koppo et al. Physical Activity Counteracts Tumor Cell Growth in Colon Carcinoma C26-Injected Muscles: An Interim Report. Eur J Transl Myol 2016;26:5958. doi: 10.4081/ejtm.2016.5958. eCollection 2016 Jun 13.
13. Barber L, Scicchitano BM, Musaro A. Molecular and Cellular Mechanisms of Muscle Aging and Sarcopenia and Effects of Electrical Stimulation in Seniors. Eur J Transl Myol 2015;25:231-6. doi: 10.4081/ejtm.2015.5227. eCollection 2015 Aug 24. Review.

14. Franzini-Armstrong C. Electron Microscopy: From 2D to 3D Images with Special Reference to Muscle. Eur J Transl Myol 2015;25:4836. doi: 10.4081/ejtm.2015.4836. eCollection 2015 Jan 7. Review.

15. Costa A, Rossi E, Scicchitano BM, et al. Neurohypophyseal Hormones: Novel Actors of Striated Muscle Development and Homeostasis. Eur J Transl Myol 2014;24:3790. doi: 10.4081/ejtm.2014.3790. eCollection 2014 Sep 23. Review.

16. Azevedo-Coste C, Vergeron V, Berkelmans R, et al. Comparison of strategies and performance of functional electrical stimulation cycling in spinal cord injury pilots for competition in the first ever CYBATHLON. Eur J Transl Myol 2017;27:251-4.

17. Sweeney HL, Hammers DW. Combination Therapies for Duchenne Muscular Dystrophy. Eur J Transl Myol 2018;28:17-8.

18. Quattrocelli M, Barefield DY, Warner JL, Vo AH, Hadhazy M, Earley JU, Demonbreun AR, McNally EM. Intermittent glucocorticoid steroid dosing enhances muscle repair without eliciting muscle atrophy. J Clin Invest 2017;127:2418-32.

19. Sabbadini RA. How the field of bioactive lipids was inspired by a discovery in the Salviati laboratory. Eur J Transl Myol 2018;28:31-2.

20. Sabbadini R, McNutt W, Jenkins G, Betto R, Salviati G. Sphingosine is endogenous to cardiac and skeletal muscle. Biochem Biophys Res Commun. 1993;193:752-8.

21. Reynolds GM, Visentin B, Sabbadini R. Immunohistochemical Detection of Sphingosine-1Phosphate and Sphingosine Kinase-1 in Human Tissue Samples and Cell Lines. Methods Mol Biol 2018;1697:43-56. doi: 10.1007/7651_2017_44.

22. Bouquerel P, Gstalder C, Müller D, et al. Essential role for SphK1/S1P signaling to regulate hypoxiainducible factor $2 \alpha$ expression and activity in cancer. Oncogenesis. 2016;5:e209. doi: 10.1038/oncsis.2016.13

23. Ganjifard M, Samii S, Kouzegaran S, Sabertanha A. The effect of positive end-expiratory pressure during anesthesia on arterial oxygen saturation after surgery in patient undergoing cesarean section. Eur J Transl Myol 2018;28:93-8.

Received for publication: March 6, 2018

Accepted for publication: March 7, 2018 